\title{
RESEARCH
}

DOI $10.23859 / 2587-8352-2017-1-3-1$

UDC 329(410)

Igor Tiapin
Doctor of Philosophy Sciences, PhD in Historical Sciences,
Professor
Vologda State University
Vologda, Russia
i.n.tyapin@mail.ru

\section{The reflection of foreign policy in Russian political thought: History and modernity}

Abstract. The article examines the problem of formation and evolution of the Russian geopolitical school as a response to the global political processes, developments and postulates which, in turn, act as a reliable conceptual basis for the formulation of a modern geostrategy for the Russian Federation. The importance of geopolitical methodology derives from its association with the principles of the systemic approach, modern scientific rationality, the unity of theoretical and empirical thoughts. The historical evolution of Russian geopolitics is traced back in the context of the $19^{\text {th }}$ early $21^{\text {st }}$ centuries, with its conceptual continuity and dynamics of ideas. It is proved that the fundamental principle of the Russian geopolitical ideal is the protection of its geopolitical space from the pressure of the Atlanticist civilization for the sake of achieving just social order, national revival and moral transformation of the mankind. The need for a new geopolitical recovery of Russia, with the effective confrontation of the subjects of globalization involves implementation of the Empire models and a new type of coherent solutions to the problems of integration of the post-Soviet space, formation of focal points for geopolitical control in the Eastern and Western hemispheres, and finally, the creation of a Eurasian continental bloc for the restoration of inter-civilizational balance.

Keywords: geopolitics, national state idea, geopolitical cycle, geopolitical consciousness, Eurasianism, monarchist traditionalism, social traditionalism, anti-globalization, fair state, geopolitical restoration

\section{Introduction}

The main features of modern international relations would be as follows: the tendency to tighten the conditions for the survival of the nation states, increasing the intensity of competition between the civilizations, approaching the "point of bifurcation' of assertion as the dominant model of the social structure or liberal totalitarianism or modernized national authoritarianism. The political, socio-cultural and eco- 
nomic changes taking place in the modern world involve practically all countries without exception into the global transformation of the existing world order. Under these conditions, the imperative principle of survival would be the preservation of civilizational identity. For Russia today, this is becoming one of the central problems that determine the vector of its development, its ultimate goals as well as its strategy and tactics for their achievement. Our country is in a situation of unprecedented political and economic pressure, the instrument of which is the theory and practice of repressive social projects and hybrid wars aimed at destroying or reformatting nations and states not shaped per the design of the United States and its satellites.

Theoretically, the achievement of the goal of preserving civilizational identity requires the use of a systematic approach, which includes, among other things, the methodological principle implying synthesis of scientific and extra scientific (including ideological) rationality. The ideology acts as an objective factor of statehood, as a form of self-consciousness of the people at the stage of statehood, called to be the basis of the national-state identity, to safeguard the continuity of the national historical existence ${ }^{1}$. Today, as never, the consolidation of scientific, political, economic and other resources is urgently necessary to implement certain breakthrough in the sphere of not only the national economy and social relations but also with regards to the spiritual culture, on which the effectiveness of the entire mechanism for ensuring the national security will depend.

Geopolitics is an example of the most organic combination of strictly scientific knowledge and ideological constructs, theory and practice. Geopolitical doctrines are a direct expression of national ideas and national-state ideologies. Geopolitics is not only a scientific discipline but also part of the ideological doctrine that is available in an explicit or an implicit form in any state. This part can be also called geostrategy a choice of foreign policy directions. The state's geostrategy depends on the leaders' understanding of the national interests and priorities, the nature and geographical distribution of threats to the country's security that originate from abroad. Where there is no life-affirming national-state idea, there is no geostrategy (nor vice versa). Per V.L. Tsymburskii, who justified the definition of geopolitics as a project political outlook and project political activity, "geopolitics begins where there is a volitional political act, let it be in the intention or in the mental model based on the intentions found in a particular space. And it is only interested in such spatial structures, which are thought of as substrata, tools and conductors of the political plans that it generates" ${ }^{2}$.

1 Molotkov A.E. Mission of Russia. Orthodoxy and Socialism in the 21st Century. St Petersburg, 2008, p. 23.

Tsymburskii V.L. Geopolitics as a world view and occupation. Polis, 1999, no. 4, p. 14. 
The geopolitical approach has had immense significance for determining the goals of Russia's foreign policy objectively in the past and the present. As A.I. Fursov notes, "space plays a special role in Russian history. In fact, it is the space (quantity and quality, i.e. as a type of landscape) which is one of the main, if not the most important, wealth (and weapons) of the Russians. And certainly, it is the main Russian substance, around which the power and social relations develop. From this point of view, the protection of the Russian space would automatically assume the protection of power and social organization - and vice versa" ${ }^{3}$. Indeed, the continental Eurasian core remained single whole, whatever the role attributed to it in the global geopolitical system. This testifies to the existence of some fundamental properties of its geopolitical position. Key features of such a region are centrality and inaccessibility to maritime communications. "In the world, as a whole," wrote H. Mackinder, "Russia occupies a central strategic position... It can strike in all directions; it can receive strikes from all sides, except the north... Any possible social revolution will not change Russia's attitude to the geographical conditions of its existence" ${ }^{4}$. This attitude derives from the eternal and organic desire to find outlets to the sea coasts, especially the nonfreezing seas: in the north - to the Baltic Sea and Barents Sea, in the south - to the Black Sea, in the east - to the Pacific Ocean. Among the most invariable geopolitical imperatives of Russia would be its position at the intersection of different cultural worlds: agricultural and nomadic, European and Asian, Christian and Muslim, Catholic and Orthodox.

Historically, geopolitics developed mainly in Anglo-Saxon (H. Mackinder, A. Macken N. Spikeman) and German (F. Ratzel, R. Chellen, K. Haushofer) scientific schools. The 'classical' discourse of Western schools, with their ideology of 'domination over the world', 'expansion of the living space', 'global domination', 'anaconda strategy', etc., it is an obvious expression of aggressive selfishness and the triumph of antivalues. All kinds of 'plans' for Russia emerging from them (E.House's plan, A.Dalles's plan, Harvard and Huston plans, S. Huntington's ideas, Z. Brzezinski's ideas, etc.) are identical in all key points, presupposing isolation of our country, falling away of its territory important in the economic and geopolitical relations of the regions, splitting of the remaining space into many local formations, tenfold reduction of population and reprogramming the consciousness of the workforce necessary for economic growth.

It is widely believed that the troubles of Russia in the last century have been caused by the 'geopolitical ignorance' and indifference, so that the governments that own such geopolitical methods beat us on the international arena. However, Russian

3 Fursov A. The Russian Ark. Famous historian on the future of Russia. Zavtra [Tomorrow], 2007, no. 5 .

${ }^{4}$ Mackinder H. The geographical pivot of history. Geographical Journal, 1904, vol. 23, p. 430. 
thought has its own (albeit often ignored by the authorities) geopolitical tradition based on a deep moral and metaphysical position and at the same time on a sober analysis of the real long-term trends in the world politics, the challenges that Russia has had to take. The situation of systemic crisis and the need for adequate responses to global challenges stimulate not only comprehension of geopolitical history and the current state of Russia from the point of view of national security and strategic interests (works by I.F. Kefeli, M.V. Remizov, V.V. Denisov, N.S. Rozov, A.S.Vladytskii, L.G. Ivashov, N.V. Luk'ianovich and others) but also understanding of the importance to appeal to the heritage of the Russian geopolitical thought and its modern transformation that has become a hot topic of research for a number of domestic philosophers and political scientists ${ }^{5}$. The results of the work now imply the need to move to the next stage, namely, to holistic comprehension of attitudes and ideals of the Russian geopolitical consciousness in its dynamics and in the context of the history of Russia's international position and foreign policy.

With regards to these, the purpose of the work is to examine the history of formation and evolution of the Russian geopolitical school as a reaction to the global foreign policy processes, threats and challenges in the world, where the findings and postulates in their turn would become an adequate conceptual basis to formulate the modern geostrategy of the Russian Federation.

\section{Main part}

Before the formation of geopolitics in Russia in its current state, their predecessors were M.V. Lomonosov in the 18th century (a treatise 'A Brief Description of Various Voyages in Northern Seas and Indication of a Possible Passage through the Siberian Ocean to East India' and other works), and in the first half of the $19^{\text {th }}$ century - the thinkers of Slavophilism and 'protection of the mir' schools, who laid the foundations of the so-called Russian idea. The categories of 'sobornost' (communal spirit) and 'peopleism' that they developed gave impetus to understanding of the role of the communal system as the ethnopsychological basis of Russia. Realizing the special nature of Russia in the world, the conservatives understood the inevitability of its opposition to the West and the fact that the contradictions between Russia and the West were insoluble at the level of civilizational principles; they proclaimed the the-

5 See, for example: K. Aksenov. Ideas of L.N. Gumilev and modern Russian geopolitics. Ethnographic Review, 2006, no. 3; Rabotiazhev N.V. Historiosophy and geopolitics of Russian conservatism: the experience of analysis. Politiia: Analysis, Chronicle, Forecast, 2007, no. 2; Iakunin V.I. Russian School of Geopolitics. St Petersburg, 2008; Gerdt Ia.V. Origins of Russian geopolitics. The Eurasian Journal of Regional and Political Studies, 2012, no. 12; Klimenko A.N. Influence of the Idea 'Moscow - the Third Rome' on Russian geopolitics of the $19^{\text {th }}-20^{\text {th }}$ centuries: thesis of candidate of Historical Sciences. Moscow, 2014. 
sis about the possibility (and duty) for Russia to become the spiritual and political leader of the mankind.

The founder of Russian geopolitics is D.A. Milyutin, the minister of war in the era of Alexander II, who designed military geography as an independent science in the 1840-50s. Milyutin defined the geopolitical priorities of Russia, considering the British Empire to be its main enemy. In his opinion, a military-political alliance between Russia and Germany was essential to maintain the equilibrium in Europe and the Middle East. In Central Asia, Milyutin did everything to subordinate the Turkestan region, which made it possible to threaten India - the basis of the might of the British Empire and at the same time its Achilles heel. The Turks, in his opinion, had to be expelled from Europe, and the Balkan Confederation had to be created under the common patronage of continental Europe, where the straits should have received a neutral status. Persia and China would receive the guarantees of the Russian Empire from all the vicissitudes of the British policy ${ }^{6}$. Thus, the calculated geopolitical move - the occupation of Turkestan - neutralized England. The military alliance with Germany gave the latter the opportunity to defeat France and thereby deprived it of the opportunity to intervene in the Balkan affairs. The situation with the Crimean War did not happen again. However, Russia was not able to enjoy the benefits from this victory. The concessions made at the Berlin Congress (instead of taking Istanbul and establishing controlled regimes in the Balkan states) became a criminal miscalculation, showing the Western blindness and lack of ideology of the supreme power. The control over the predominantly Slavic, Orthodox Balkans would have made Russia the master of Rimland forever. Instead, the Balkans turned into a region irreversibly controlled by the West.

The 1860-70s became the time when Pan-Orthodox was supplemented by PanSlavism in Russia's foreign policy. As a geopolitical doctrine, Pan-Slavism was reflected in the project of the pan-Slavic Orthodox federation, developed by $\mathrm{N}$. Danilevsky, where Russia acts as the driving force, because it is the only one of all the Slavic peoples that "makes its great universal decisions, which become the law of the life of peoples for entire ages, without intermediaries, surrounded by thunder and lightning, like Sabaoth from the top of Mount Sinai" ${ }^{7}$. And the union must be created in such a way that "the Slavic streams do not merge in the Russian sea", i.e. all Slavs must preserve their national identity, political and cultural independence. Danilevsky saw Tsargrad-Constantinople as the political centre of such a federation.

Within the framework of the morphological methodological principle, N. Danilevsky showed that the cultural-historical types do not fundamentally mix and

6 Morozov E.F. The last field-marshal. Russian Geopolitical Collection, 1997, no. 2, p. 36.

Danilevsii N.Ia. Russia and Europe. St Petersburg, 1995, p. 254. 
change only on a historical scale, based on ethnic qualities, developed by the landscape and historical evolution (what Jung later referred to as the 'archetype'). Analysing Russia's relations with the European countries, the thinker noted that they were often unequal and unprofitable for Russia. History, he rightly argued, taught that the expansion from the West was a permanent phenomenon. For the security of Russia and the entire Slavic world, per Danilevsky, it is necessary to be able to achieve the disunity of goals of England, France, Germany, Austria - their unification is always dangerous for the Russians and all the Slavs.

General R.A. Fadeev put forward the hypothesis of a single center for the conceptual management of the world and for the first time proposed methods of geopolitical confrontation. The root of the eastern question is for him to subordinate and Germanize the Slavs in the original efforts of the German race; hence the need to unite the scattered Slavic tribes under Russia's primacy and the inevitability of an energetic Russian policy directed mainly against Austria ${ }^{8}$. The idea of combating the coalition of the Western powers - Austria, Prussia and England - did not embarrass the general at all, who was also known as a geopolitical practitioner, organizer of the Pan-Slav movement, military adviser in the Egyptian and Montenegrin armies, commander of the Serbian army in 1876.

The radical conservative K.N. Leontyev shifted his emphasis to the analysis of Russia's historical connection with Byzantine civilization and the Middle East aspects of its foreign policy, calling to shake off the 'Romano-German ashes from our Asian soles'. Leontyev, in contrast to the founders of Slavophilism, concluded that most of the Slavs had already irreversibly gone into the degrading Western civilization, into the ranks of the enemies of Russia, the only civilizational subject potentially capable of (and obliged) to show the world a new, higher type of flowering culture. "Russia is not just a state; Russia, taken in full with all its Asian possessions, is a whole world of special life, a special state world that has not yet found its own style of cultural statehood," he wrote, calling for the development of "our own, original, Slavic-Asian civilization" centred in Constantinople, completely different from the European civilization with its triumphant philistinism. "Tsargrad," asserted Leontyev a century and a half ago, "is that natural centre to which all Christian nations should gravitate, sooner or later ... destined to form with Russia a great Eastern Orthodox Union". "Then there will be two Russias ...: Russia the empire, with a new administrative capital (in Kiev) and Russia the head of the Great Eastern Union with a new

8 Fadeev R.A. Opinion on the Eastern Question. URL: http://litresp.ru/chitat/ru/ $\Phi /$ fadeevrostislav-andreevich/kavkazskaya-vojna/6.

9 Leont'ev K.N. Temple and Church. Moscow, 2003, p. 146. 
cultural capital on the Bosporus" ${ }^{\prime 10}$, a conservative thinker dreamed of, seeing nothing utopian in the creation of a colossal kingdom in the manner of the Macedonian empire.

The foreign policy of Alexander III (Nicholas II tried unsuccessfully to act in line with it) was to renounce the conflicts with the European powers to firmly consolidate his positions in Central Asia, Eastern Siberia and the Far East. For this reason, Miliutin's direction of geopolitical thought became the main one at the turn of the $19^{\text {th }}$ and $20^{\text {th }}$ centuries, providing several notable names (V.F. Golovachev, A.I. Voeikov and others), among which special attention deserves the figure of V.P. Semenov-TianShansky.

Tian-Shansky, Jr. explained the nature of world domination and expansion in the context of synthesis of the marine and continental parts of the globe. The former interpretation of the global power of states based only on the thesis of British geographers with regards to dichotomy and eternal confrontation of land and sea seemed simplistic and one-sided to him. Tian-Shansky identified three forms of "territorial systems of political power" that had existed in history: 1) a circumferential system (the Mediterranean under the rule of the Roman Empire, Byzantium, the Ottoman Empire, etc.); 2) a parcelled system (scattered over the seas and oceans of individual islands and pieces of continents - the colonial empires of Spain, Portugal, Holland, partly - England), which led to fairly rapid depletion of the forces of the metropolis; 3 ) the system 'from sea to sea'. The scientist paid his greatest attention to the system of domination 'from sea to sea', which, in his opinion, was first implemented by Alexander of Macedonia, and which Russia and the USA repeated in the modern times. The main disadvantage of this type of the system is stretching the territory and uneven settlement. In the situation with Russia, the threat to its existence as a territorial system is created by the weakened eastern end wedged between the climatically severe territories of the north of Asia and the "original lands of the vast state of multimillion-strong yellow race".

V.P. Semenov-Tian-Shansky considered the increase in population and economic development of the geographical center of the territory as the 'way out' for Russia. Then the extreme eastern part would be approached by a few thousand 'versts' to the middle part of the state and would can withstand the struggle with the external enemy much more successfully. The integrity of the Russian state implied reorganization of the dualistic geographical representation, per which the state would be artificially divided by the Ural ridge into the European and Asian parts ${ }^{11}$. According to SemenovTian-Shansky, it is necessary to single out Russian Eurasia as a cultural and eco-

10 Ibid., p. 210.

11 Semenov-Tian-Shanskii V.P. About the powerful territorial possession regarding Russia. Essay on Political Geography. Spatial Economics, 2008, Issue 2, p. 145. 
nomic unit equal in rights to European Russia on the space between the Volga and the Yenisei from the Arctic Ocean to the southernmost borders of the state. The cultural and economic centre could be moved to the true geographical centre in two ways: either by transferring the capital (for example, to Ekaterinburg) or by forming new colonization oases - cultural and economic centres (Baikal, Altai, etc.). At the same time, the scientist opposed the administrative and territorial federalization of Russia as, undoubtedly, the course that was disastrous if going for it.

A considerable contribution to the 'treasury' of geopolitical thought was made by I.A. Ilyin, whose ideas (stimulated by the confrontation of our country in the two World Wars) in this regard resonating with the theory of the 'father' of Western geopolitics, R. Chellen. Like the latter, Ilyin believed that the state, the country with its population, is a 'living organism'. Russia has evolved over centuries, not as a 'mechanical sum of territories' and "accidental piling up of territories and tribes", but as an organic unity that is not subject to arbitrary partition, in the formation of which the land and the geographic environment play a decisive role. On this occasion, he wrote: "From the very first centuries of their existence, the Russian people found themselves on a conventionally divisible and open plain, open from all sides. There were no fencing lines; since the ancient times, there was a great 'pass-through yard' through which the 'migrating peoples' were flooding in - from the east and southeast to the west. Therefore, Russia was an organism, eternally forced to self-defence" 12 . Ilyin, who defined Russia as "the geographical organism of large rivers and remote seas", considered the policy of Russian sovereigns quite normal, consisting in getting out to the seas and "making a firm foot at sea", to master the lower reaches of the rivers. Noting that "Russia ... is a stronghold of the European-Asian and therefore universal peace and equilibrium" "13 Ilyin emphasized that the attempts to dismember its body have always been the cause and symptom of the general crisis. In the newest time, in his opinion, the whole universe will be dragged into this process, the strife and civil wars in Russia will constantly grow into world clashes, the powers of the whole world will invest their money, interests, strategic calculations in newly emerged small states and compete, seeking the predominance of the 'strongholds'.

The Eurasians (N.S. Trubetskoi, P.N. Savitskii, N.N. Alekseev, G.V. Vernadskii, L.P. Karsavin etc.) were the first to use the very notion of 'geopolitics' in Russian thought. Unlike previous generations of Russian philosophers, Eurasianism has made the images of space as the main angle of view that helps to understand Russia as an 'organism of natural size' better against the background of other civilizations. It is appropriate to quote P.N. Savitskii, who wrote: "The geography junction with histo-

12 Il'in I.A. Our tasks. Coll. Op. T. 2. Book 1. Moscow, 1993, p. 297.

13 Ibid., p. 326-327. 
riosophy means imposition of the grids of historical signs that characterize RussiaEurasia as a special historical world, onto the grid of geographic features"14.

The Eurasianists accepted the discovery of H. Mackinder about the central axis of history and redesigned his category 'the Heart of the Earth' into the concept of 'Eurasia in a narrow sense' (in modern terminology - 'historical Eurasia') in contrast to "Eurasia in the broadest sense of the word" (now 'Eurasia geographic'). By "Eurasia in a narrow sense of the word", the steppe zone stretching from the Great Khingan to the Middle Danube plain is meant, the events on which, per H. Mackinder, determine the destinies of the world ("The Steppe strip is the backbone of history"). This is the place of development (the Eurasian term) of the Continental civilization, in all its foundations as opposed to the Oceanic civilization (European, Romano-Germanic). The borders of the Eurasian developmental place coincide with the borders of the Russian Empire and the USSR, which is not accidental. These are the natural boundaries of a Eurasian cultural-historical type.

Given that the main stimulus for the development of Russia, as a rule, was an external threat, the Eurasian project assumed rejection of imitation in all spheres of life, the idea of doctrinal synthesis, i.e. a combination of openness and dynamism with tradition and conservatism, where economic forms and instruments (autarky, multistructure, business initiative) should serve the development of science and art, strengthening the social solidarity and country's defense capability.

Relating to the events of World War II, an upward wave of the geopolitical cycle led our country at the highest geopolitical maximum in its history by the end of the 1940s and early 1950s. There was gradual restoration of the positions of the Russian state in the form of the USSR and under the flag of communism. The Soviet Union, whilst rejecting geopolitics, was at the same time very geopolitical; in the Soviet period, the messianic, idealistic essence of the country's foreign policy was preserved, however on a different ideological basis. The Communist ideology, on the one hand, allowed giant geopolitical breakthrough, but it also became a delayed-action mine, suppressing Russian national identity and justifying the creation of semi-state entities on different levels that could become sovereign. With I.V. Stalin, throughout the boundaries of the Heartland, the system of limitotropic states was created, serving as its 'own' sanitary cordon. The USSR was one of the two centers of a bipolar system. The Soviet superpower existed in its historical borders as an integrated and protected geopolitical space. Moreover, the USSR was active in the belt of the 'Inner' and 'Outer Crescent' (Egypt, Syria, Laos, Yemen, Mozambique, Ethiopia, Angola, Afghanistan) in the 1960-70s. These actions did not bring any real effect for strengthening the geopolitical security, because they did not rely on economic pragmatism or a

14 The world of Russia is Eurasia. Moscow, 1995, p. 229. 
strategy (unlike the American 'anaconda loop', when in the coastal zone of Eurasia (with the exception of India) NATO and SEATO military blocs created CENTO and numerous naval bases). This system embedded the most daring projects of Russian tsars and geopoliticians but soon lost its historical dynamics, as it united too diverse states socially, politically and politically-ideologically, whose mentality transformed the communist ideology. The USSR was an empire built the other way around (when the periphery in many ways lives at the expense of the metropolis), and it could not exist for long.

The narrowing of the Russian geopolitical space after the collapse of the USSR led to the emergence of qualitatively new nature and the state of interstate demarcation in the form of 'near' and 'far' abroad. Being pushed back to the northeastern part of Eurasia, the 'independent' Russian Federation lost some of its outlets into the world ocean as well as the most important communication routes connecting it with the West and the South. Its resource base, productive capacity and financial and economic potential diminished sharply. Russia found itself surrounded by the states that are under the influence of the United States and its NATO allies creating military bases on their territories. To dictate their conditions to Russia and to nullify its geopolitical influence, the West needs a weak and fragmented country that has been pushed to the "margins of history". The former 'anaconda strategy' now assumes gradual tightening of the loop throughout the entire former Soviet Union. Already in the 2000s, the partition of Russia was expected by analogy with the USSR with the transformation of fragments of Russian statehood into the colonial economic space.

The ideological basis of this program included several main points, of which the most important were as follows: 1) the presumption of Russia's guilt as an incorrigibly imperialist state that threatens the stability of Europe and the world (in contrast to the supposedly post-imperial West); 2) the thesis that the time of empires has ended (ignoring the undeniable fact that the US, the European Union, TNCs are all variants and models of the 'new type of empire'); 3) the call for 'objectively necessary' rejection of all foreign policy ambitions and geopolitical claims, in connection with economic difficulties, in the name of concentration of forces and focusing exclusively on internal problems; 4) operation with the 'objective' law, consisting in the fact that the intensive expansion of the area of the people's livelihood generates and preserves extensive forms of management and economic life in general, which also has a significant negative impact on the cultural and political development of the country ${ }^{15}$.

In the situation of conducting such a foreign policy, the activity on the revival of the national geopolitical school within the framework of the public Institute of Geo-

15 Makeev A.V. The geopolitical course of Russia in security coordinates. Space and Time, 2010, no. 2, p. 109. 
politics begun in the 1990s by A.G. Dugin, A.M. Anisimov. S.A. Shatokhin, etc., was considered quite natural. The external name of the doctrine is neo-Eurasianism, and on its own it is called the continental ('civilizational') school. V.V. Kozhinov, V.V. Maliavin, A.S. Panarin, V.Ia. Pashchenko, etc. worked in the said direction. The neoEurasianism developed a geopolitical version of this concept in the context of the Russian idea, which claims to be a valid theoretical basis for the development of a geostrategy for modern Russia.

The need to overcome the crisis of the society and the state became the main reason for creative mastering of the patriotic thought by the neo-Eurasians by appealing to the ideas and concepts of H. Mackinder, K. Haushover, the German 'conservative revolutionaries' E. Jünger, K. Schmitt, etc., and the use of L.N. Gumilev's concepts of 'passionarity' and 'super ethnos'. The orientation towards the strategy of national antiglobalism, the desire to achieve 'demotic ideocracy', multipolarity, civilizational and historical contextualization of the economic activity as a whole can ensure the fullness of social life about which A.S. Panarin wrote as follows: "The civilizational process has two interconnected aspects: instrumental-pragmatic, infrastructural designed to provide a single economic, informational and legal space, as well as spiritual value aimed to give this space the highest sacral (value) meaning"16. The mission of Russia, as Panarin believed, is to implement the Eurasian civilizational project, in other words, the creation of Eurasian civilization on the post-Soviet space: "The Russian idea in Eurasia was associated with messianism, willingness to assume responsibility for the state of this part of oecumene, share the burden of existence with friendly peoples, jointly building the future" ${ }^{\text {17 }}$. At the same time, he hoped that the Eurasian project could become a consolidating force for the entire non-Western world in its resistance to globalism.

The most thorough version of neo-Eurasianism geopolitics was the concept of a new Eurasian empire developed by A.G. Dugin.

Like M.N. Katkov, who transferred the Hegelian historiosophic conception to Russian reality, Dugin writes: "Hegel developed an interesting concept that the Absolute idea in an eschatological situation should manifest itself in the final, 'conscious' form as a Prussian state. However, on a planetary scale, Prussia, and even Germany, taken separately, are geopolitically inadequate ... Russia, the Third Rome, perfectly corresponds religiously, culturally, spatially and strategically to such a teleological view of the essence of history and clearly strives to fulfill precisely the mission to create a "continental Kingdom of Absolute Idea"18. The Eurasian empire, "the build-

16 Panarin A.S. Russia in Cycles of World History. Moscow, 1999, p. 239.

17 Panarin A.S. Challenge (Geopolitical pessimism against civilizational optimism). Political Science in Russia: Intellectual Search and Reality. Moscow, 2000, p. 88.

18 Dugin A.G. Fundamentals of Geopolitics. Moscow, 1997, pp. 197-198. 
ing of which would correspond to the global, planetary civilizational mission of Russian people", is conceived as a multilevel formation, the 'empire of empires', the "confederation of Major Spaces", among which four are the most distinguished - the European empire in the West, the Pacific Empire in the East (around Japan), the Central Asian empire in the south (around Iran) and the Russian Empire in the center of Eurasia (around Russia). In addition, it is assumed that there are several other 'Major Spaces' - around India and China, based on the Arab world, as well as the PanAfrican Union. The continental integration of Eurasia with a center in Russia can guarantee its people the real sovereignty. Russia's civilizational choice in politics is the assertion of "a special isolated humanity". Russia should not merge with the world, until the world becomes Russia.

The modern right ('Orthodox-monarchical', 'white') traditionalists gravitate towards organic understanding of the society and the nation (each nation for them is a build-up of historical organisms). Therefore, the disintegration of the USSR is often perceived by them in the spirit of I.A. Ilyin as unnatural dismemberment of the organic whole. Thus, per V.N. Osipov, geographically and territorially, the USSR and Russia are one and the same thing, and the "Belovezhsky conspiracy of December 1991 is a crime, not in the sense of liquidation of the illegal, illegitimate, Bolshevikcompiled Soviet Union but in the sense of dismembering the organically united and indivisible 1000-year-old state organism"19. The essential incompatibility of the Russian and Euro-Atlantic civilizations is postulated by the approach. For example, E.S. Kholmogorov connects the opposition of Western and Russian civilizations with the fact that in their foundation, different types of action are underlying - goal-orientated and value-rational one (in the terminology of M. Weber). The basis of Western capitalism, per Kholmogorov, is a goal-orientated action: the subject sets a clear goal and strives to achieve it; the outside world and other people are treated by him only as means for achievement. "The Russian civilization is built on a different type of action - the value-rational one, for which the unconditional value, the given high social ideal is of primary importance over the goal itself and sets the rational structure of certain semantic and not only the target content" ${ }^{\prime 20}$.

Right-wing traditionalists emphasize the centuries-old deep Western rejection of Russia in two of its manifestations: "as an equal geopolitical force and a historical personality with its own search for the general meaning of the universe - an obstacle to the destruction of the diverse world transformed by today's messianic project of

19 Osipov V.N. Russian Field. Moscow, 1998, p. 119.

20 Kholmogorov E.S. Russian Nationalist. Moscow, 2006, p. 251. 
liberal globalization into a cultural and economic province of Anglo-American world"21.

Geopolitical attitudes of modern social-traditionalism, the slogan of which is the unity of national power and social justice, are graphically represented in the works of S.N. Baburin, where the key geopolitical idea is the functioning of Russia as the creator of a new global order, which can be based on the principle of a multipolar dispersal of power ${ }^{22}$.

Baburin notes that Russia has almost never been a national state in its classical sense, immediately having formed itself as a union of different ethnic groups with two fastening rods: the Russian language and Orthodoxy. Hence, the self-awareness of the Russian (Eastern Christian) civilization (the content of the community) and the Russian empire (its form) grew. Like any civilization, Russian is not a closed system, it seeks through external affairs (politics, economics and, above all, culture and science) to carry out its attitude to those outside $\mathrm{it}^{23}$. In the $20^{\text {th }}$ century, historical Russia passed through the tragedy of destruction twice (1917 and 1991). After the first occasion, it managed to restore its natural boundaries; the Soviet system was a special civilization that in a relatively short time had passed all cycles of civilizational development: from the heroic period of nomination of a new social ideal through wars and a period of stability, to "fatigue, loss of faith and limp fading". At the beginning of the $21^{\text {st }}$ century, we have the Russian civilization, which is in dispersion.

The main geopolitical concept for Baburin is the 'Russian world' understood as a cultural and historical community that transcends national states and political systems, based on a different system of values and interests. From this perspective, the space of the Russian world includes almost the entire territory of the former USSR, as well as Serbia and Montenegro (despite the change in elites in these countries). The political core of the Russian world should be the union state of Russia and Belarus, turned from amorphous education into a capable political subject represented in the UN Security Council, a "great power based on the Russian culture and the Russian language" capable of repelling the expansion of the West and the East, rejecting the globalist unification. Per S.N. Baburin, the Russian imperial idea is characterized by a complex set of religious and ideological ideas about the eschatological meaning and purpose of Russian statehood. The imperial approach means not only a strong power, but also a fair power, under which every person is guaranteed all opportunities for

21 Narochnitskaia N.A. Russia and the Russians in World History. Moscow, 2003, p. 214.

22 Baburin S.N. The world order as a system of possession of territories. Our Contemporary, 2006, no. 7, p. 217.

${ }^{23}$ Baburin S.N. The Return of Russian Conservatism. Moscow, 2012, p. 14. 
comprehensive development and a dignified life. Not at the expense of other people, but together with them ${ }^{24}$.

\section{Conclusion}

Thus, the geopolitical ideal of Russian national thought has undergone some transformation as the historical situation and state evolution change. At the same time, its essential features for more than a century and a half have remained the same. A fundamental principle is the protection of its geopolitical space from the pressure of the Atlantic civilization for the sake of implementing the model of a just social order, national liberation and moral transfiguration of the mankind.

Contemporary national-orientated geopolitical thought is, in fact, imbued with the belief that in the confrontation with the global dictatorship, the traditional - despotic or oligarchic - regimes based on former shapes of statehood and practices of social management are doomed to be defeated in the information-ideological and technological war. Only a state that is large in space and population, orientated on the commandment of absolute morality that is nationally expressed, can effectively resist the Western hegemony, building on its basis the political and legal activity, that has independent ideology and development strategies based on a national idea, alien to corruption and oligarchy. Consequently, the existence of Russia in the future is possible only as a state with imperial features, which differs both from the medieval empires of the East and the European colonial powers of modern times, as well as from the 'reverse empire' - the USSR. After all, despite the geopolitical catastrophe that took place, Russia remains a continental force, an independent subject of the world politics, playing the role of a geopolitical balance in the expanses of Europe and Asia. "The destinies of a new century's confrontation are being decided in Russia," A.S. Panarin concludes. - "Not only because Russia is the owner of the world's largest territory, whose resources do not allow global privatizers to sleep. Russia is the owner of the most spiritually exalted, noble and chaste cultural tradition, without breaking resistance of which the population of the Eurasian Heartland cannot be turned into a human mass devoid of real dignity" 25 .

We can state the presence of geopolitical consciousness as a special form of the Russian theoretical public consciousness. The Russian geopolitical consciousness unites traditions and approaches both of classical geopolitics, and of the new (geoeconomics) and the newest (geophilosophy / geo-ideology) geopolitics. The 'core' of this consciousness is the belief that the historical experience of the existence of the Russian civilization shows that its geopolitical achievements and victories were ac-

${ }^{24}$ Ibid., p. 20.

25 Panarin A.S. Strategic Instability. Moscow, 2003, p. 345. 
complished in the presence of clearly defined, consistent tasks, in their turn based (directly or indirectly) on the national idea at the metaphysical level, shared by the authority and the people; in other words, Russian geopolitics has always been ideocratic. In such cases, Russia sometimes won even with a disadvantageous ratio of potentials (military, economic, demographic) compared to their geopolitical opponents. On the contrary, failures and defeats, military and diplomatic, accompanied Russia almost always in its absence or in the event of its discredit, even in the situation of advantage or equality of forces, because the "non-national non-ideological" led to total opposition of the values of the society and the authority, and (in the context of global struggle of the worldviews) of disorientation and the inevitable spiritual degradation of the latter.

Hence the vision of the geostrategy of modern Russia stems as a long-awaited civilizational format in the sense of "modernization returning to its origins".

Politically and economically, this is a reform within the framework of the project of a moral state of justice - a new version of the 'mobilization model', considering the objective interests of the majority ${ }^{26}$. The anti-Western political vector set by the reunification with the Crimea cannot last forever without implementing an adjusted strategic scheme of internal social and economic development.

Ideologically, the geopolitical reconstruction should be based on the thesis that the expansion of the Russian state objectively responded to the security interests of ethnic groups living in Eurasian spaces. Its territorial growth was due to the needs of arranging a system of stable and safe economic activity, inclusion into the world production and economic relations. Overall, it also responded to the needs of spiritual development of the peoples who entered the system, through their involvement with the world values through the great Russian culture.

The geopolitical task of a minimum is integration of the post-Soviet space. The likely initial (requiring only minimal political will) step may be the 'confederation of Rus' within the Russian Federation, Belarus and Novorossia (at least within the limits of today's DNR (Donetsk People's Republik) and LNR (Lugansk People's Republic). Maintaining the basic elements of the state sovereignty of its constituent parts, the confederation could have coordinating bodies that are publicly functioning, original symbols, common currency and act as a single entity in such areas as culture and sport. It is necessary to use various forms of control over the space of the former USSR, the distinct diplomatic recognition of pro-Russian autonomies (Transnistria, Abkhazia, South Ossetia), the real support of Russian diasporas in the Baltic, Ukraine, Kazakhstan, Central Asia, the discussion with the leaders of the member

${ }^{26}$ For more details see: Tiapin I.N. The moral state as the state of justice: strokes to the concept. Philosophy of Law, 2016, no. 6. 
states of EAEU of their anti-Russian political rhetoric, regulation of migration from the neighboring countries and beyond.

The task of the middle level is the formation of centers of geopolitical control in the space of the Eastern and Western hemispheres (Latin America: Cuba, Venezuela, Middle East). It is very important here: a) to weaken as much as possible the unity of the organization of the geopolitical opponents (for example, the EU), taking advantage of their real problems and contradictions; b) strengthen the relations with those countries that do not allow to 'close in' - Iran, India, China, Syria, Vietnam, etc.

The task maximum (which cannot be solved without implementation of the first and second tasks) is the unification of the Eurasian, African, Islamic, Hindustan and Far Eastern civilizations into a single Eurasian continental block to restore the intercivilization balance.

\section{References}

1. Aksenov K.E. Idei L.N. Gumileva i sovremennaya rossijskaya geopolitika [The Ideas of L.N. Gumilev and contemporary Russian geopolitics]. Ehtnograficheskoe obozrenie [Ethnographic Review], 200, no. 3, pp. 44-53. (In Russian)

2. Baburin S.N. Vozvrashhenie russkogo konservatizma [The Return of Russian Conservatism]. Moscow: Institut russkoj tsivilizatsii, 2012. 832 p. (In Russian)

3. Baburin S.N. Mirovoj poryadok kak sistema obladaniya territoriyami [World order as a system of owning land]. Nash sovremennik. [Our Contemporary], 2006, no. 7, pp. 202-224. (In Russian)

4. Danilevskij N.Ya. Rossiya i Evropa [Russia and Europe]. St Petersburg: Glagol, 1995. 552 p. (In Russian)

5. Dugin A.G. Osnovy geopolitiki [The Foundations of Geopolitics]. Moscow: Arktogeya, 1997. 608 p. (In Russian)

6. Fadeev R.A. Mnenie o Vostochnom voprose [Opinion on the Eastern question]. Available at: http://litresp.ru/chitat/ru/F/fadeev-rostislav-andreevich/kavkazskaya-vojna/6 (date of access: 29.04.2017). (In Russian)

7. Fursov A. Russkij kovcheg. Izvestnyj istorik o budushhem Rossii [Russian ark. Wellknown historian on Russia's future]. Zavtra [Tomorrow], 2007, no. 5. (In Russian)

8. Gerdt YA.V. Istoki rossijskoj geopolitiki [The origins of Russian geopolitics]. Evrazijskij zhurnal regional'nykh i politicheskikh issledovanij [Eurasian Journal of Regional and Political studies], 2012, no. 12, pp. 26-30. (In Russian)

9. Holmogorov E.S. Russkij natsionalist [Russian Nationalist]. Moscow: Evropa, 2006. 432 p. (In Russian)

10. Il'in I.A. Sobranie sochinenij [Collection of Works] v 10 t. T. 2. Kniga 1. Nashi zadachi [Our Objectives]. Moscow: Russkaya kniga, 1993. 496 p. (In Russian)

11. Klimenko A.N. Vliyanie idei 'Moskva - Tretij Rim' na rossijskuyu geopolitiku XIX $X X v v$. [The Impact of the Idea 'Moscow - the Third Rome' in Russian geopolitics the $19^{\text {th }}-$ $20^{\text {th }}$ centuries. Doctoral dissertation]. Moscow, 2014. 24 p. (In Russian) 
12. Leont'ev K.N. Khram i Tserkov' [The Temple and the Church]. Moscow: AST, 2003. 636 p. (In Russian)

13. Mackinder H. The geographical pivot of history. Geographical Journal, 1904, vol. 23, pp. 421-437.

14. Makeev A.V. Geopoliticheskij put' Rossii v koordinatakh bezopasnosti [Geopolitical role of Russia in the coordinates of the security]. Prostranstvo $i$ vremya [Space and Time], 2010, no. 2, pp. 107-116. (In Russian)

15. Mir Rossii - Evraziya: antologiya [The World of Russia - Eurasia: Anthology]. Moscow: Vysshaya shkola, 1995. 399 p. (In Russian)

16. Molotkov A.E. Missiya Rossii. Pravoslavie i sotsializm v XXI veke [Orthodox Christianity and Socialism in the $21^{\text {st }}$ century]. St Petrsburg: Russkij ostrov, 2008. 395 p. (In Russian)

17. Morozov E.F. Poslednij fel'dmarshal [The last field-marshal]. Russkij geopoliticheskij sbornik [Russian Geopolitical Collection], 1997, no. 2, pp. 34-38. (In Russian)

18. Narochnitskaya N.A. Rossiya i russkie v mirovoj istorii [Russia and the Russians in the World History]. Moscow: Mezhdunarodnye otnosheniya, 2003. 536 p. (In Russian)

19. Osipov V.N. Russkoe pole [Russian Field]. Moscow: Desnitsa, 1998. 170 p. (In Russian)

20. Panarin A.S. Rossiya $v$ tsiklakh mirovoj istorii [Russia in the Cycles of World History]. Moscow: Moskovskij universitet, 1999. 288 p. (In Russian)

21. Panarin A.S. Strategicheskaya nestabil'nost' [Strategic Instability]. Moscow: Algoritm, 2003. 560 p. (In Russian)

22. Panarin A.S. Vyzov (Geopoliticheskij pessimizm protiv tsivilizatsionnogo optimizma) [Call (Geopolitical pessimism vs civilizational optimism)]. Politicheskaya nauka v Rossii: intellektual'nyj poisk i real'nost' [Political Science in Russia: Smart Search and Reality]. Moscow, 2000, pp. 80-94. (In Russian)

23. Rabotyazhev N.V. Istoriosofiya i geopolitika rossijskogo konservatizma: opyt analiza [Historiosophy and geopolitics of Russian conservatism: experience of analysis]. Politiya: analiz, khronika, prognoz [Polity: Analysis, News, Forecast], 2007, no. 2, pp. 103-116. (In Russian)

24. Semenov-Tian-Shanskii V.P. O mogushchestvennom territorial'nom vladenii primenitel'no k Rossii. Ocherk po politicheskoj geografii [About the powerful territorial possession with reference to Russia. Essay on Political Geography]. Prostranstvennaya ehkonomika [Spatial Economics], 2008, no. 2, pp. 144-160. (In Russian)

25. Tiapin I.N. Nravstvennoe gosudarstvo kak gosudarstvo spravedlivosti: shtrikhi k kontseptsii [Moral state as the state of justice: touches to the concept]. Filosofiya prava [Philosophy of Law], 2016, no. 6 (79), pp. 57-62. (In Russian)

26. Tsymburskij V.L. Geopolitika kak mirovidenie i rod zanyatij [Geopolitics as a world view and occupation]. Polis: politicheskie issledovaniya [Polis: Political Studies], 1999, no. 4, pp. 7-28. (In Russian)

27. Shestakov S.A. Politicheskij konservatizm v postsovetskoj Rossii [Political Conservatism in Post-Soviet Russia]. Moscow: Prometej, 2003. 168 p. (In Russian)

28. Yakunin V.I., Zelenev V.I., Zeleneva I.V. Rossijskaya shkola geopolitiki [The Russian School of Geopolitics]. St Petersburg: Sankt-Peterburgskij universitet, 2008. 367 p. (In Russian) 